Proc. Estonian Acad. Sci. Geol., 1990, 39, N 1, 7-11

удК 551.468 .1

Eric BIRD, Ena MARTIN, Kaarel ORVIKU

\title{
REED ENCROACHMENT ON ESTONIAN BEACHES
}

In recent decades, reeds (Phragmites australis) and some associated rushes have been intensively spreading on Estonian sandy beaches, notably on the shores of Pärnu Bay, the Võsu beach, the northern and western shores of Lake Peipsi and Lake Vorrtsjärv. Some sections that were formerly beach-fringed are now bordered by up to 100 metres wide reedswamp vegetation zone: for example, at Liu, southwest of Pärnu, the beach that existed in the last century has disappeared behind and beneath swamp vegetation (Fig. 2). At Raeküla, east of Pärnu, the reedswamp has advanced seawards across the sandy beach (Fig. 3), which is now exposed only during the summer period of low sea level, while at Valgeranna, north of Pärnu, and Uulu, southeast of Pärnu, the reedswamps which occupy the shore have been extending laterally on to the beach sands. On the northern shore of Lake Peipsi a $40 \mathrm{~km}$ long beautiful sandy beach stretches from Lohusuu to Vasknarva. According to local people there was no vegetation on the shore forty years ago. At present about $1 / 3$ of sandy beach is covered by reed vegetation and it cannot be used for recreation any more (Мартин, 1986).

The largest reedswamp territory in Estonia lies in the central part of the Matsalu Nature Reserve, in the Kasari River delta area (Fig. 1). As a result of the neotectonic uplift $(2.5 \mathrm{~mm} / \mathrm{year})$ and the accumulation of mineral and plant deposits, the reedswamp border of the bay has shifted as far as $2.5 \mathrm{~km}$ westwards during the present century (Ksenofontova, 1985). Extensive reed growth mostly depends on the hydrological and hydrochemical regimes of the bay. Such hydrological conditions as shallow

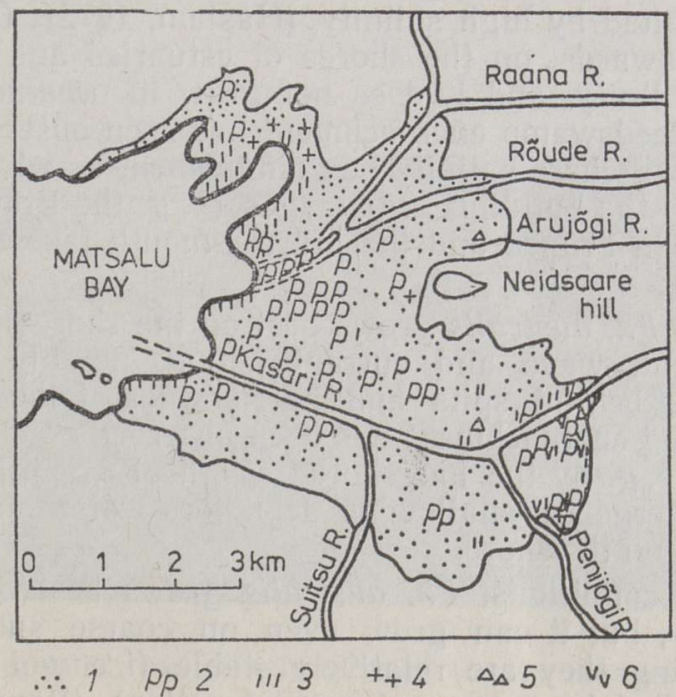

Fig. 1. Distribution of the reeds in the delta of the Kasari River. 1 - Phragmites australis, 2 - Typha angustifolia, 3 - Schoenoplectus lacustris et S. tabernaemonteni, 4 Bolboschoenus maritimus, 5 - Acorus calamus, 6 - Glyceria maxima (by Ksenofontova, 1985). 
water (the mean depth $1.5 \mathrm{~m}$ ) and high water temperatures in summer (the mean temperature of July is about $20^{\circ} \mathrm{C}$, the absolute maximum being $26-27^{\circ} \mathrm{C}$ ), as well as a long period of subzero temperatures (Mardiste, Kaasik, 1985) are quite favourable for reed development. The chemical composition of the water in Matsalu Bay is formed mainly by the invasion of brackish sea water from the west, by the inflow of fresh river water from the east, and by the water plants of the bay. Besides the natural factors the hydrochemical regime of the bay is also influenced by human activities. During the last decades a significant increase of mineral nutrients in the bay water due to the inflow from the Kasari River and runoff from neighbouring farmlands has been observed (Porgassaar, Simm, 1985).

Early stages in the establishment of reeds and rushes can be seen at the southern end of the beach in Narva Bay, which has been cut bask and lowered by erosion during the past 10 years. Scattered fragments of reed and rush rhizomes have been washed on to the beach, and those that come to rest on damp sand have begun to grow up as new vegetation.

\section{Factors that favour reed growth}

The spread of Phragmites has been largely vegetative, by the breaking off of rhizome segments which drift on to the beach and begin to grow into new reed colonies, but it is possible that some reeds have germinated from seed deposited on the beach. Studies of the invasion of lagoon and lake, as well as the Baltic Sea shores by Phragmiles have indicated a number of physiographic and ecological factors relevant to reed encroachment (Bird, 1961; Лымарев, 1967; Ksenofontova, 1985). These include:

1. Water depth. Ph. australis can spread into water of about 0.5 metres deep where all other conditions are favourable. Once such a limit has been attained, shallowing by land uplift or sea level lowering, or by accretion of sediment or peat deposits, may lead to further encroachment.

2. Salinity. Ph. australis grows best in fresh or slightly brackish water, but is limited by high salinity (Haslam, 1972). On oceanic coasts it diminishes seawards, on the shores of estuaries and lagoons towards areas of high salinity, and it does not grow in oceanic water (average salinity $35 \%$ ). Reedswamp encroachment has been observed on the shores of coastal lagoons where salinity has diminished, as where sea water has been excluded by the building of barrages (e. g. the Etang de Vaccres on the Rhone delta in France and the Murray-mouth lakes in South Australia) (Bird, 1978).

3. Exposure. Ph. australis grows best on the shores that are sheltered from strong wind, wave and current action, notably in estuaries and coastal lagoons, behind spits and barriers, or at the heads of shallow embayments. Reed encroachment has been observed on shores that become more sheltered, e. g. by the longshore growth of a spit. It would also be facilitated by emergence, shallowing nearshore waters and thus diminishing wave energy on the shore.

4. Substrate conditions. Ph. australis grows best on fine sediments (silt, clay, peat), but it can grow even on coarse substrates (pebbles, cobbles) providing they are relatively stable (i. e. not being frequently disturbed or drifted by wave and current action) (Ranwell, 1972). Reed enchroachment can occur where a coarse substrate besomes stable, especially if it is being gradually covered by finer sediment, silt and clay. A sandy beach that is becoming lower, flatter, finer and damper provides ideal conditions for the spread of reed vegetation. 


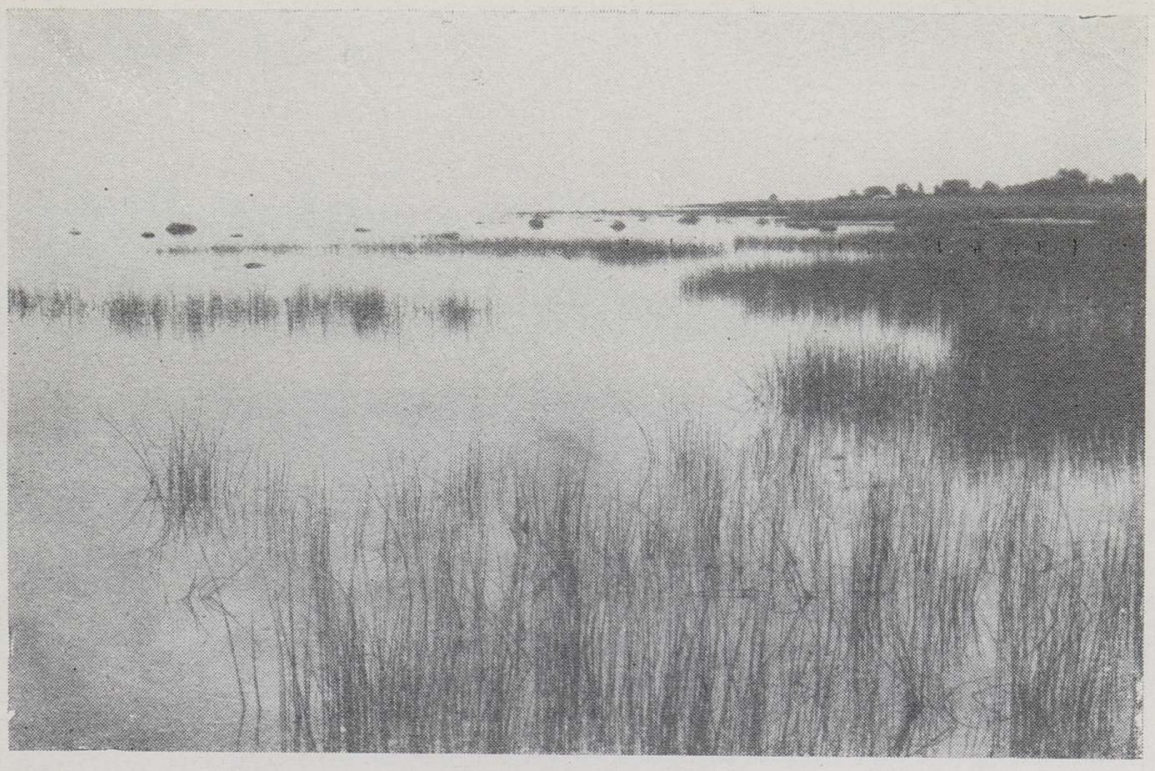

Fig. 2. Reed spread in the eastern part of the Pärnu beach under the effect of waste waters inflow.

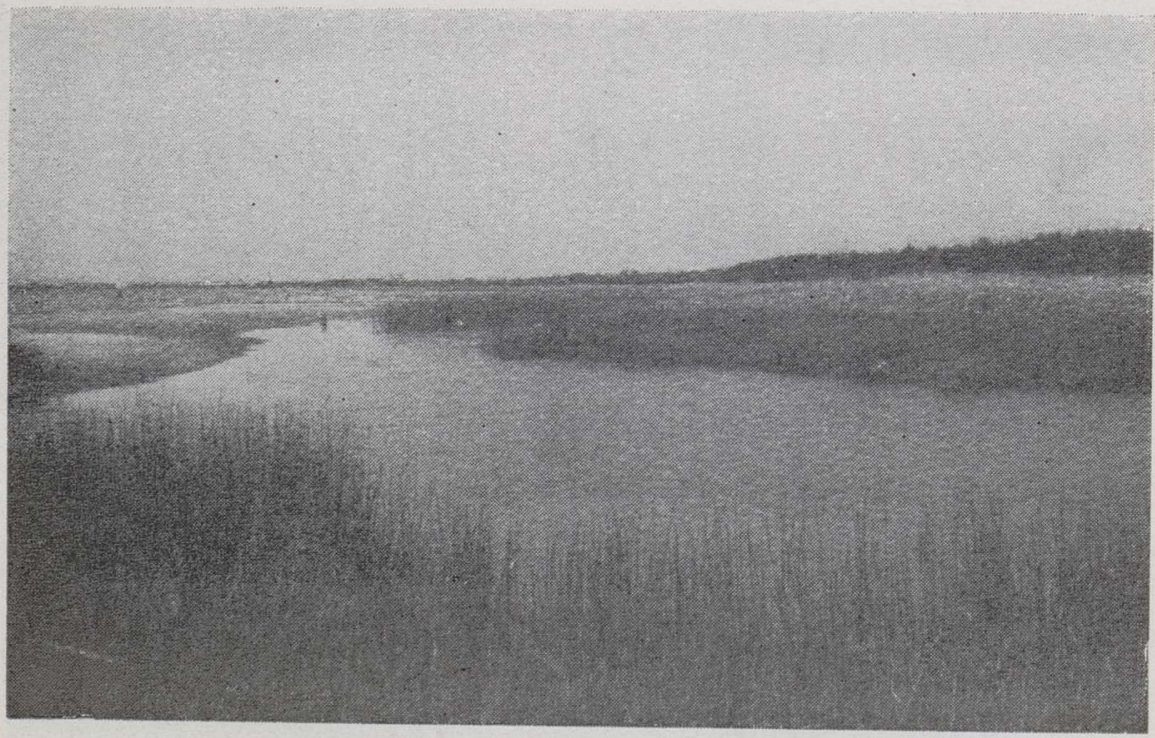

Fig. 3. Beach vegetation has entirely occupied the low southwest coast of Pärnu Bay. 


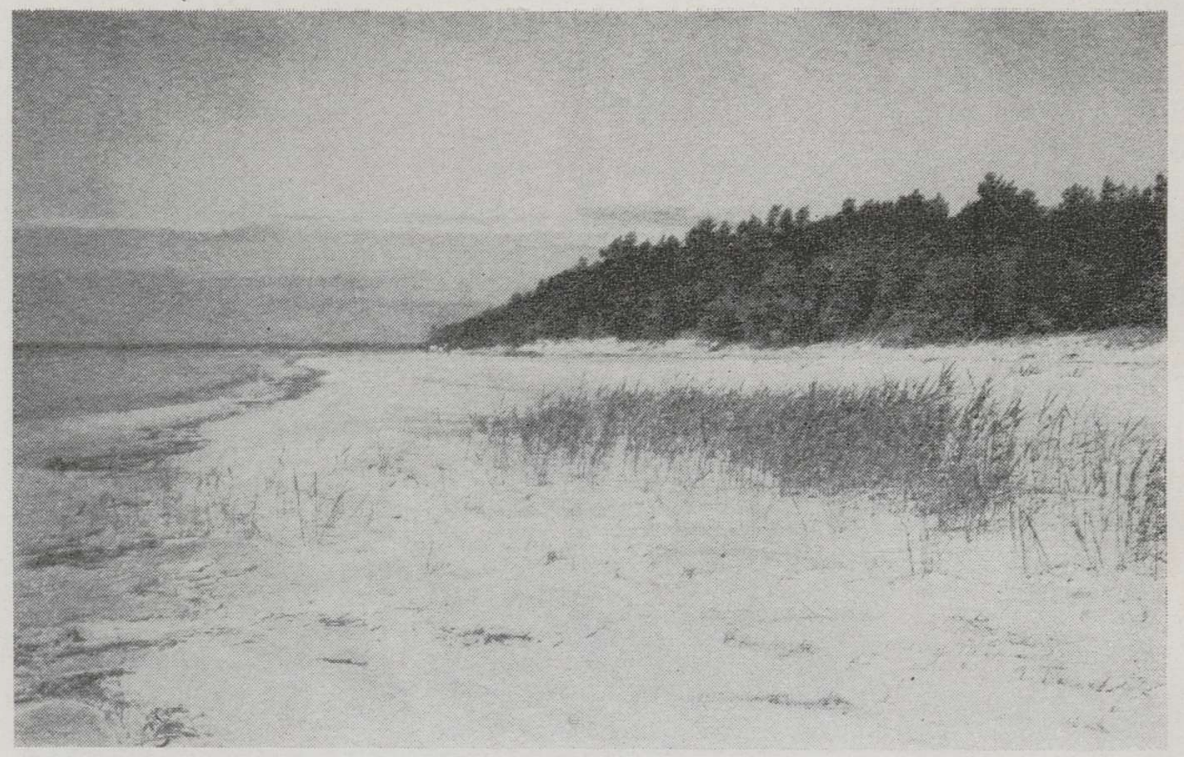

Fig. 4. The encroachment of beach vegetation has started also in the eastern part of the Valgeranna prograding beach.

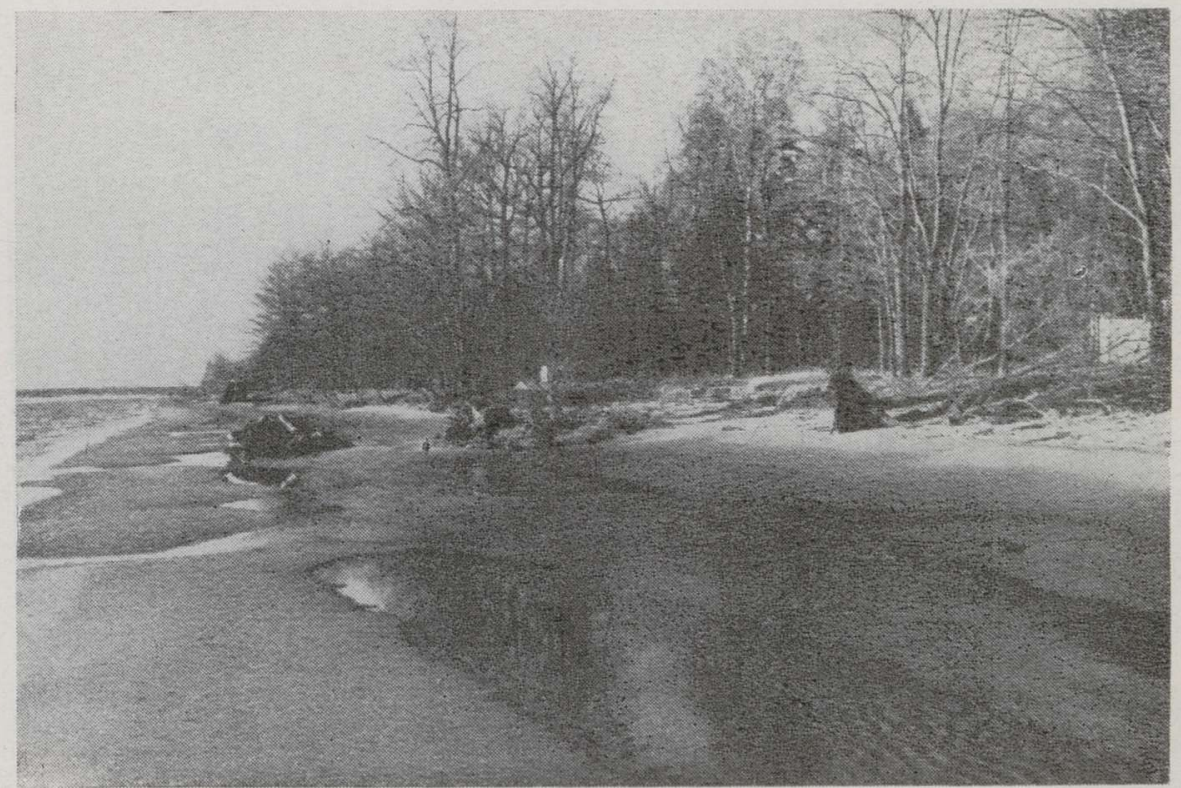

Fig. 5. In the western part of the Valgeranna resort storm damages have intensified in last decades. 
5. Nutrient status. Ph. australis growth is very sparse in water that is poor in nutrients (oligotrophic), but it improves as soon as the concentration of dissolved salts, especially phosphates and nitrates, increases (Haslam, 1972; Ranwell, 1972). In particular, reed growth in water that begins to receive runoff from farmland, containing fertilisers, or sewage, containing phosphates, nitrates and other compounds, becomes more luxuriant.

\section{Reed encroachment on beaches}

In terms of these factors, the situation of Estonian sandy and silty shores may be reviewed. Ph. australis has certainly become more abundant on Estonian shores (e.g. the eastern and western shores of Pärnu Bay, the eastern upper part of Matsalu Bay, small bays in North-Estonia, on the shores of big lakes), and this may be partly due to shallowing of the nearshore areas as a result of continuing land uplift (the reason does not suit for big lakes). This is especially the case because the Estonian nearshore sea floor is not sandy, but consists of silt, clay or peaty sediments, the emergence of which is highly suitable for reed growth.

Salinity is not a limiting factor for Ph. australis on the shores of the Baltic Sea. In general, the nearshore salinity does not exceed $7 \% 0$ on the Estonian coast (Soviet Estonia, 1978), and reeds will grow in much more brackish water than that.

Exposure to wave and current action may have changed slightly in the areas, where the land uplift has been shallowing nearshore waters. Locally, the growth of spits or barriers may have reduced exposure on a shore section.

Substrate conditions have changed where beaches have been cut back and lowered by erosion, and this is certainly a major factor in the observed reed encroachment in Estonia. On the beach at Valgeranna, for example, there is a contrast between the eastern section, which is prograding, and has low dunes developing behind a beach that is broad, high and slightly convex in profile (Fig. 4), and the western section, where the dune margin has been cliffed and the beach profile is lower and flatter (Figs 5 and 6). As the fine sand is lowered, it becomes damp, intersecting the water table, and it also acquires silt and clay particles. Such conditions permit the spread of phragmites and associated rushes along the shore. The Pärnu beach consists also of fine sand, and it is often overwashed by waves where it forms a low, gently convex barrier in front of the reedswamp zone east of the town. If the beach were higher

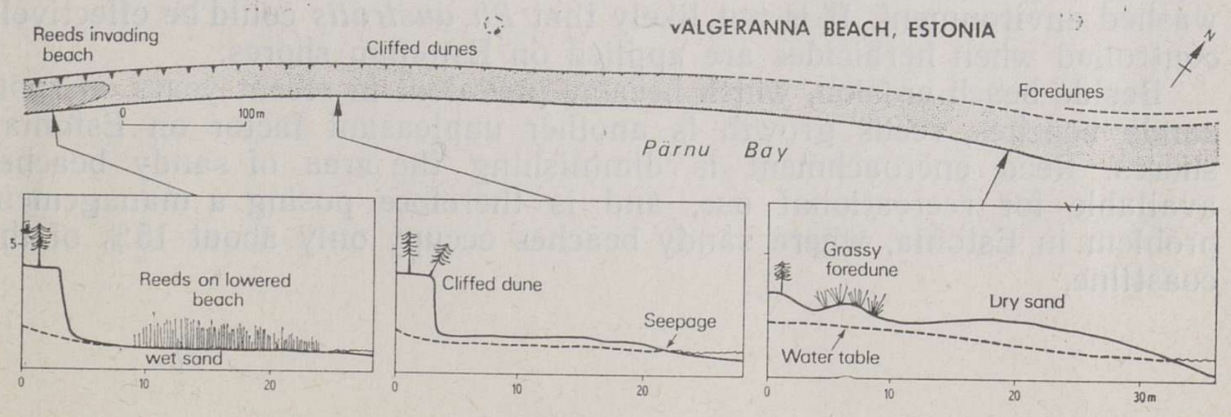

Fig. 6. Reed encroachment on the Valgeranna Beach, Pärnu Bay, Estonia. Phragmites is invading the western end of the beach, which has been cut back and lowered by erosion in recent decades. Sand has drifted north-eastwards to a prograding sector of the beach, which is wider and higher, and backed by grassy foredunes. 
and wider it would form the more permanent barriers, but the repeated overwashing has reduced it to a level on which $P h$. australis can advance seawards.

According to Urve Ratas (pers. comm.) with the ceasing of cattle raising and mowing the reed started to spread towards the interior part of small islands near the Estonian western coast, and in some places reed is growing even on pebble beach ridges.

An additional factor is the increase in nutrient status, especially in phosphates and nitrates, resulting from agricultural and industrial pollution of coastal waters. Such pollution results in eutrophication, which certainly aids the spread of reeds, and promotes luxuriant growth.

\section{Prevention of reed growth}

In terms of this analysis, the quickest and most effective way to prevent the spread of $P h$. australis on sandy beaches would be to artificially raise beach levels by emplacing sand (if possible, coarse sand) brought from inland quarries or dredged from the nearby river channels or from the adjacent sea floor. Artificial beaches are usually formed as a high terrace, the surface standing above the level of the highest tidesor the maximum seasonal high sea level (Schwartz, Bird, 1989). In Estonia it would provide higher and drier beaches above the limits of, and of a form and texture unfavourable to, colonisation by $P h$. australis. In Estonia an experiment was carried out on the Võsu resort beach, which is situated on the top of a small Käsmu Bay (North-Estonia). The low coast, flat sea floor and inconsiderable sediment drift, as well as the Võsu River, which discharges into the bay in the vicinities of the sandy beach, favoured the distribution of the plant cover on the beach. During several years the beach needed clearing from vegetation and the sand from the coastal slope was pushed to the beach every spring. This means did not help much - the beach remained low and damp. At the end of 1987 the beach level was artificially raised by emplacing sand from an inland quarry. In September 1988 the beach was still wide and high, without vegetation.

At the same time it would be useful to reduce pollution of coastal waters by untreated (or only partially treated) sewage and farm runoff, thereby making conditions less favourable for $P h$. australis invasion. This would also improve the quality of coastal waters for swimming.

An attempt has been made to destroy vegetation that has encroached on to beaches by spraying herbicides. This was tried in Sand Bay, near Weston super Mare in England in the nineteen sixties, when Spartina grass encroached on a sandy shore, but the vegetation killed was soon replaced by new growth, the herbicides being impersistent in a wave washed environment. It is not likely that $P h$. australis could be effectively controlled when herbicides are applied on Estonian shores.

Beside beach erosion, which became prevalent in recent years on some sandy beaches, reeds growth is another unpleasant factor on Estonian shores. Reed encroachment is diminishing the area of sandy beaches available for recreational use, and is therefore posing a management problem in Estonia, where sandy beaches occupy only about $15 \%$ of the coastline.

Bird, E. C. F. Reed growth in the Gippsland Lakes // Victorian Naturalist. Melbourne, 1961. 
Bird, E. C. F. The Geomorphology of the Gippsland Lakes region. Ministry of Conservation, Melbourne, Publication 186, 1978.

Haslam, S. M. Community regulation in Phragmites communis // J. Ecology, 1972, 59, $75-88 ; 60,585-610$

Ksenofontova, T. Matsalu lahe pilliroog ja roostikud // Matsalu - rahvusvahelise tähtsusega märgala. Tallinn, 1985, 113-124.

Mardiste, H., Kaasik, T. Matsalu lahe ja Kasari jõe hüdroloogiline režiim // Matsalu rahvusvahelise tähtsusega märgala. Tallinn, 1985, 15-26.

Porgassaar, V., Simm, H. Matsalu lahe hüdrokeemiline režiim // Matsalu - rahvusvahelise tähtsusega märgala. Tallinn, 1985, 26-36.

Ranwell, D. C. Ecology of salt marshes and sand dunes. London, 1972.

Schwartz, M., Bird, E. C. F. Artificial nourishment of beaches // J. Coastal Research (in print).

Soviet Estonia. Land, People, Culture. Tallinn, 1980.

Лымарев В. И. Берега Аральского моря - внутреннего водоема аридной зоны. Л., 1967.

Мартин Э. Проблемы строения и абразии береговых дюн северного побережья Чудского озера // Изв. АН ЭССР. Геол., 1986, 35, № 2.

Melbourne University

Academy of Sciences of the Estonian SSR, Institute of Geology
Received

March 9, 1989

\section{Eric BIRD, Ena MARTIN, Kaarel ORVIKU}

\section{KORKJATE LEVIKUST EESTI RANDADEL}

Viimase paarikümne aasta jooksul on Eesti mererandade keskkond märkimisväärselt halvenenud. Kõrvuti süveneva abrasiooniga ilmneb ka randade kinnikasvamine. Artiklis on toodud andmeid pilliroo ja kõrkjate levikust Eesti randadel ning viidatud tegureile, mis soodustavad taimestiku vohamist ja liivarandade kinnikasvamist. Selle peapõhjuseks näib olevat rannikumere saastatus. On kirjeldatud meetmeid, mida on kasutatud supelrandade kaitseks nii meil kui ka mujal.

\section{Эрик БЭРД, Эна МАРТИН, Каарел ОРВИКУ}

\section{О РАСПРОСТРАНЕНИИ ТРОСТНИКА НА ЭСТОНСКОМ ПОБЕРЕЖЬЕ}

В течение последних двадцати лет состояние пляжей Эстонии значительно ухудшилось. Помимо интенсивной абразии намечается тенденция их зарастания. В последние годы распространению тростника и тростниковых зарослей способствует большое количество растительных питательных элементов, принесенных водным стоком из районов интенсивного сельского хозяйства или из населенных пунктов. 